\title{
CAVERNOUS SINUS INVASION BY PITUITARY MACROADENOMAS
}

\author{
NEURORADIOLOGICAL, CLINICAL AND SURGICAL CORRELATION
}

\author{
ARTHUR CUKIERT***, MARIO ANDRIOLI***, JAYME GOLDMAN*/**, \\ MARCIA NERY****, LUIS SALGADO****, MIRTA KNOEPFELMACHER**, \\ FERNANDO PIMENTEL ***, BERNARDO LIBERMAN****
}

\begin{abstract}
The classical imaging gold-standard for this diagnosis is the presence of tumor lateral to the carotid artery. Seventeen patients with pituitary macroadenomas with intraoperative confirmation of cavernous sinus invasion were studied with MRI. Only 8 patients had tumor lateral to the carotid artery; 13 had tumor within the carotid syphon and all lacked the ring enhancement of the medial wall of the cavernous sinus. In 10 patients, widening of the posterior double leaflets of the cavernous sinus could be. All patients were operated by the transesphenoidal route. Only one patient was cured by surgery alone. Only 3 patients disclosing the above mentioned MRI features were identified in a series of 250 patients and did not have cavernous sinus invasion. The present criteria proved to be useful in the pre-operative diagnosis of cavenous sinus invasion and patients' counselling. Pre-operative diagnosis of cavernous sinus invasion of pituitary tumors has a great impact in the management of such patients.
\end{abstract}

KEY WORDS: pituitary tumors, magnetic resonance image, cavernous sinus invasion.

\section{Invasão de seio cavernoso por tumores pituitários: correlação neurorradiológica e clínico-cirúrgica}

RESUMO - O critério imagenológico clássico para diagnóstico de invasão de seio cavernoso é a presença de tumor lateralmente à carótida em cortes coronais. Estudamos 17 pacientes com macroadenomas hipofisários com ressonância compátivel a invasão de seio cavernoso e que tiveram esta invasão confirmada cirurgicamente. Somente 8 destes pacientes possuíam tumor lateralmente à carótida (critério clássico). Treze pacientes possuíam tumor localizado entre as porções intracavernosas da carótida e em todos havia ruptura da captação anelar de contraste no seio cavernoso. Dez pacientes possuíam abertura dos folhetos posteriores do seio cavernoso. Todos os pacientes foram tratados por via transesfenoidal. Somente um caso obteve cura endocrinológica. Somente 3 pacientes portadores de algum destes sinais imagenológicos foram identificados em uma série de cerca de 250 casos e não possuíam invasão de seio cavernoso. Os critérios acima parecem adequadamente permitir prever a invasão do seio. Este diagnóstico é relevante já que a maioria dos pacientes com invasão de seio cavernoso acaba realizando terapia complementar.

PALAVRAS-CHAVE: tumor hipofisário, ressonância magnética, seio cavernoso invasão.

Cavernous sinus invasion by pituitary adenomas has been noted since the early days of pituitary surgery ${ }^{1}$. On the other hand, the pre-operative diagnosis of cavernous sinus invasion was rarely done before the introduction of CT scanning in the clinical practice and correctly performed only in the more obvious cases by means of $\mathrm{CT}^{2}$. The availability of high resolution MR imaging ${ }^{3}$ has made it possible to study the sellar region in a detail not possible using CT scans ${ }^{4}$. Different criteria have

Departments of Endocrinology and Neurosurgery, Hospital Brigadeiro, Sao Paulo SP, and HypothalamusPituitary Unit, Department of Endocrinology, Hospital das Clínicas USP: *Department of Endocrinology, Hospital Brigadeiro, São Paulo-SP; **Department of Endocrinology, Hospital das Clínicas, USP; ***Department Neurosurgery, Hospital Brigadeiro, São Paulo-SP. Aceite: 13-outubro-1997.

Dr. Arthur Cukiert - R. Nova York 744 / 131 - 04560-001 São Paulo SP - Brasil. 
been suggested to standardize the neuroradiological diagnosis of cavernous sinus invasion by pituitary adenomas $^{5,6}$. Unfortunately, the pituitary / medial wall of the cavernous sinus interface is poorly visualized even with MRI and that explains why no definite criteria have been accepted so far.

The prevalence of radiological and surgical findings compatible with cavernous sinus invasion has been increasing over the last decades. This plays an important role while treating these patients since cavernous sinus invasion is usually related to uncomplete surgical removal of the tumour, poor endocrinological results and the need for adjuvant therapy, especially the different types of radiation therapy.

This study reports the MRI findings in patients with pituitary macroadenomas and try to establish guidelines for the neuroradiological pre-operative diagnosis of cavernous sinus invasion in such patients.

\section{METHODS}

Seventeen patients with pituitary macroadenomas (2 prolactinomas, 4 with Cushing's disease, 7 with acromegaly and 4 with non-secreting tumors) that were submitted to transesphenoidal tumor resection and had intraoperative confirmation of cavernous sinus invasion were included in this study. Intraoperative diagnosis of cavernous sinus invasion was based on the visual inspection of this structure and clear signs of invasion. Discoloured or rough medial walls were not rated as "invasion".

Pre-operative MRI scanning consisted of multiple T1 coronal slices through the sellar region with and without the administration of paramagnetic contrast. Post-contrast thin $\mathrm{T} 1$ axial slices of the sellar region were also obtained. A sagittal sequence was acquired for diagnostic purposes but was not used to define cavernous sinus invasion.

Different MR features were especifically studied in coronal (presence of tumor lateral to the carotid artery, within the carotid syphon and loss of the ring enhancement of the medial wall of the cavernous sinus) and axial (oppening of the double posterior leaflets of the cavernous sinus) slices.

\section{RESULTS}

In 8 patients, MRI disclosed tumor lateral to the carotid artery; 13 patients had tumor located within the carotid syphon and all had loss of the ring enhancement of the medial wall of the cavernous sinus as defined by MRI (Fig 1). In 10 patients, opening of the double posterior leaflets of the cavernous sinus could be seen in axial slices (Fig 2).

Only 1 (GH-secreting) of the 13 patients with secreting tumors with cavernous sinus invasion was cured by surgery alone. This patient had a progressive decline in GH levels over the first week and probably had a subacute necrosis of intracavernous tumor. All patients with secreting tumors not cured by surgery alone $(\mathrm{n}=12)$ were submitted to post-operative radiation therapy.

\section{DISCUSSION}

The presence of tumor lateral to the carotid artery in patients with pituitary adenomas has been considered the classic gold-standard for the pre-operative radiological diagnosis of cavernous sinus invasion ${ }^{7}$. It is present in the bigger tumors ${ }^{8,9}$. On the other hand, it is conceivable that if tumour can be often seen lateral to the carotid artery, that it could have been seen medial to it or within the carotid syphon in an earlier phase. Actually, the challange today is to define guidelines to identify early invasion of the cavernous sinus by pituitary tumors.

We have studied patients with pituitary macroadenomas. In these patients, lack of the ring enhancement of the medial wall of the cavernous sinus seems to be the first sign of cavernous sinus invasion and was seen in all patients. Tumor within the carotid syphon was also seen in the majority of the cases and seems to be related to a more advanced stage of invasiveness. The posterior leaflets of the cavernous sinus were also frequently widened, as could be seen in axial slices. Axial slices are not routinely acquired in MR imaging of the sellar region but it should be included in the protocol if cavernous sinus involvement is suspected. The prevalence of the reported cavernous sinus invasion 

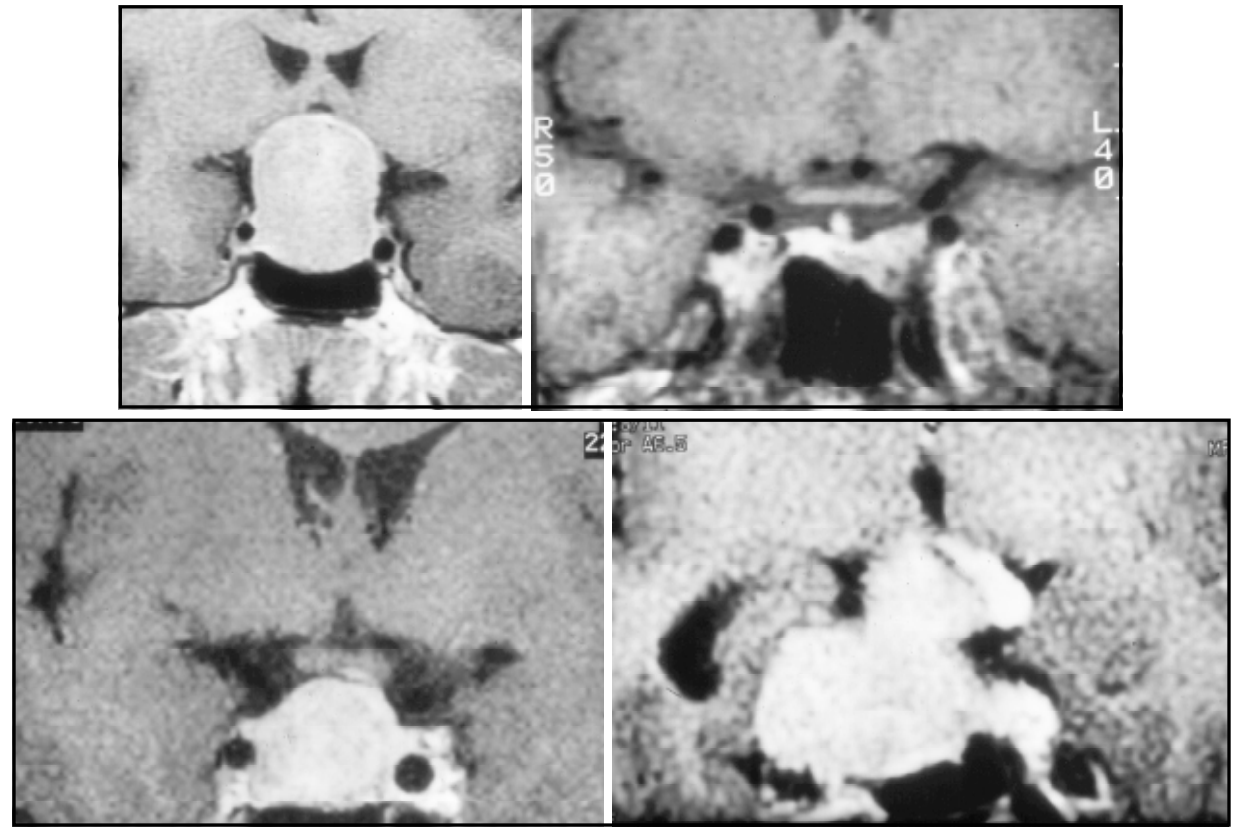

Fig 1. T1-enhanced MR coronal slices of the sellar region showing progressive stages of cavernous sinus involvement. Left-superior: macroadenoma with no cavernous sinus invasion. Right-superior: macroadenoma occupying the mid-and left compartments of the sella, there is loss of the ring-like enhancement of the left cavernous sinus; Left-inferior: macroadenoma occupying the whole sella, displacing the gland to the left and invading the right cavernous sinus, there is no ring-enhancement of the right cavernous sinus and tumor can be seen within the carotid syphon. Right-inferior: macroadenoma with parasellar extension and cavernous sinus invasion, tumor can be seen lateral to the carotid artery.

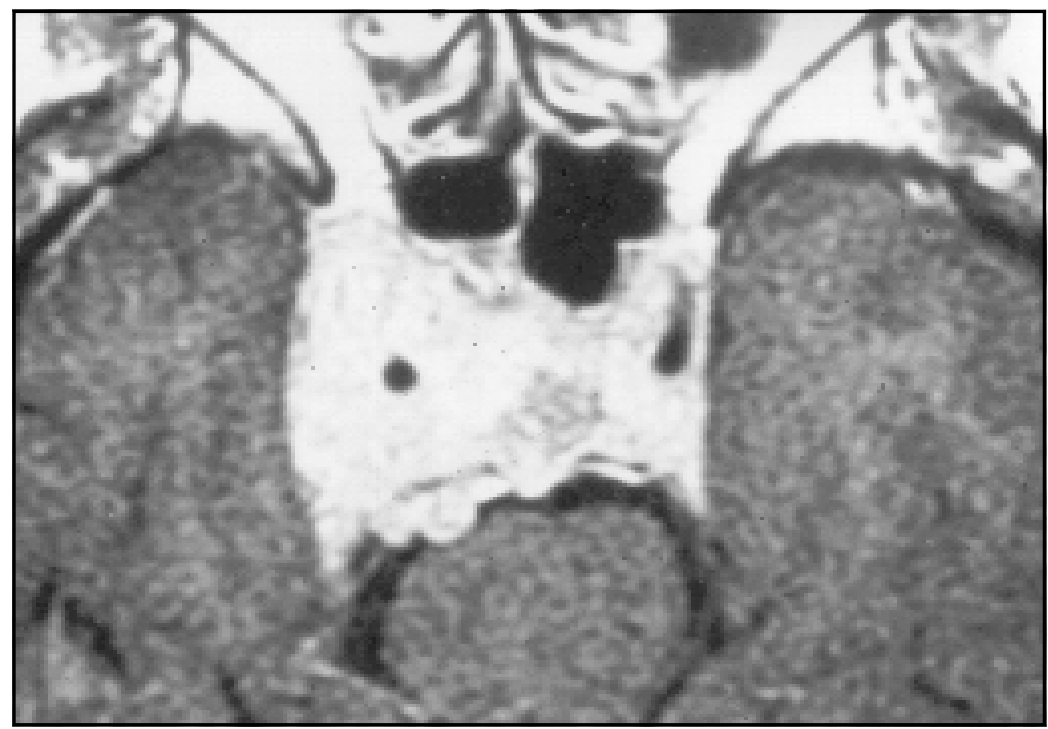

Fig 2. T1-enhanced axial MR slice showing an invasive macroadenoma with a clear opening of the posterior double-leaflets of the right cavernous sinus. Tumor is also seen lateral to the carotid artery. 
by pituitary tumors has risen in recent years. It is probably even higher than presently reported ${ }^{10}$. It should be noted that microscopic dural invasion can be seen in patients in whom the surgeon reported no intraoperative invasiveness ${ }^{11}$.

This study did not include microadenomas but patients with microadenomas can also have cavernous sinus invasion ${ }^{12}$. This situation might correlate to the $10 \%$ failure rate for endocrinological cure in patients with microadenomas. We are presently carrying out the evaluation of the meaning of early signs of cavernous sinus invasion as defined by MRI in the prognosis of patients with microadenomas.

Interestingly, the only (acromegalic) patient with cavernous sinus invasion cured by surgery had a sub-acute cure which is quite different from what is seen conventionally in patients cured by surgery, especially in tumors which secrete hormones with a very small half-life ( e.g., GH). We postulated that this patient has had a progressive post-manipulation necrosis of the intracavernous portion of the tumor and achieved cure.

The multiple radiological patterns of cavernous sinus involvement requires an individualized analysis of each patient. Imaginary lines and compartments are not useful to standardize this diagnosis ${ }^{13}$.

Only 3 patients disclosing the presently analyzed MRI criteria for cavernous sinus (CS) invasion and with intraoperative findings not confirming CS invasion were found in a series of 250 patients. Taken together with the data from this study, it seems that the analised MR criteria in macroadenomas could provide useful guidelines for the pre-operative diagnosis of cavernous sinus invasion and patients' counseling. How these features apply to microadenomas has yet to be seen.

\section{REFERENCES}

1. Martins AN, Hayes GJ, Kempe LG. Invasive pituitary adenomas. J Neurosurg 1965;22:268-276.

2. Nichols DA, Laws ER, Houser OW, Abboud CF. Comparison of MRI and CT in the preoperative evaluation of pituitary adenomas. Neurosurgery 1988;22:380-385.

3. Daniels DL, Czervionke LF, Bonneville JF, et al. MR imaging of the cavernous sinus: value of spin-echo and gradient recalled echo images. Am J Roentgenol 1988;151:1009-1014.

4. Davis PC, Hoffman JC, Spencer T, Tindall GT, Braun IF. MR imaging of pituitary adenoma: CT, clinical and surgical correlation. Am J Roentgenol 1987;148:797-802.

5. Komiyama M. MRI of the cavernous sinus. Radiat Med 1990;8:136-144.

6. Komiyama M, Hakuba A, Yasui T, et al. MRI of intracavernous pathology. Neurol Med Chir Tokyo 1989;29:573-578.

7. Ahmadi J, North CM, Segall HD, Zee CS, Weiss MH. Cavernous sinus invasion by pituitary adenomas. Am J Roentgenol 1986;146:257-262.

8. Kaufman B, Kaufman BA, Arafah BM, Roessmann U, Selman WR. Large pituitary gland adenomas evaluated with MRI. Neurosurgery 1987;21:540-546.

9. Scotti G, Yu CY, Dillon WP, et al. MR imaging of cavernous sinus involvement by pituitary adenomas. Am J Roentgenol 1988;151:799-806.

10. Selman WR, Laws E, Scheithauer E, Carpenter S. The occurrence of dural invasion in pituitary adenomas. J Neurosurgery 1986;64:402-407.

11. Daita G, Yonemasu Y, Nakai H, Takei H, Ogawa K. Cavernous sinus invasion by pituitary adenomas: relationship between MRI findings and histologically verified dural invasion. Neurol Med Chir Tokyo 1995;35:17-21.

12. Hirohata T, Uozumi T, Mukada K, et al. Microprolactinoma invading the cavernous sinus: report of three cases. Neurol Med Chir Tokyo 1992;32:10-12.

13. Knosp E, Steiner E, Kitz K, Matula C. Pituitary adenomas with invasion of the cavernous sinus space: a magnetic resonance imaging classsification compared to surgical findings. Neurosurgery 1993;33:610-618. 